\title{
Stability Analysis of Lotka-Volterra Model in The Case of Interaction of Local Religion and Official Religion
}

\author{
Tri Hidayati ${ }^{1 *}$, Wiwit Kurniawan ${ }^{2 *}$ \\ 1,2 Pamulang University \\ ${ }^{*}$ Corresponding author: \\ Email: trihidayati@unpam.ac.id, wiwitkurniawan@unpam.ac.id
}

\begin{abstract}
.
The purpose of this research is to examine the interaction of local religions and official religions using the Lotka Volterra equation model. This study uses a literature study, which means that all the material in this study is taken, collected and compiled from various existing book sources. The steps in this study are to find the equilibrium point of each equation, then examine the behavior of each equilibrium point obtained. In this study, an analytical study of the prey population model has three equilibrium points, namely

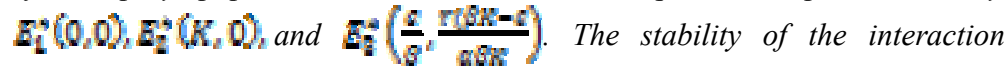
between local religions and official religions is achieved at an equilibrium

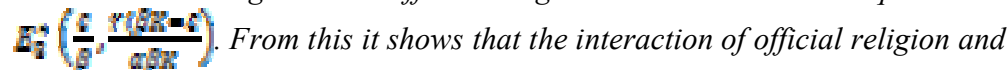
local religion does not necessarily lead to the extinction of a religion. The interaction of local religious and official religion there is a point of equilibrium, where the social reality they can work in harmony.
\end{abstract}

Keywords: lotka volterra, stability, interaction, local religion, official religion

\section{INTRODUCTION}

Indonesia is a country that is very rich in diversity. There are various ethnic groups, cultures, languages and religions. This diversity is a blessing, but on the other hand there is the potential for conflict and friction between these different entities. One of the things that often raises horizontal conflicts is issues related to religion. In the understanding of the Indonesian government, local religion is not considered a form of "religion", but is considered a faith or belief system (Aliran Kepercayaan). Even in the past, they could not include the names of their beliefs in the Identity Card (KTP) column. There were cases which they could not make an ID card which caused them to be unable to access government services. Thus, politically and administratively, adherents of local religions are under a lot of pressure. In addition to political-government problems, local religions are also faced with the problem of religious conversion. Currently, there are fewer people who are affiliated with or adhere to local religions because they are converting to the official religion. Several cases occurred in various parts of Indonesia where adherents of the Aliran Kerpercayaan converted to the official religion. The Samin community has many adherents who have converted to Islam [1]. In addition, Hasse J (2016) in his study "The Dynamics of Relations between Islam and Local Religion in Indonesia", said that many Towani Tolatang in Sulawesi converted to Islam [2].

Likewise with the Tengger community who have chosen various official religions In the Riau region, the same thing also emerged, namely the religious conversion of the Rawa Anak Tribe which was converted into Christianity, Buddhism, Confucianism, and a small part of Islam [3]. This phenomenon shows that there is an eliminative interaction between local religion and official religion. In the above phenomenon, there are two problems that can arise, namely the loss of local religious traditions and the emergence of resistance from local religions which can lead to conflict and conflict. From this problem, it is necessary to have a point of stability or equilibrium that becomes a solution to the conflict between the two religious groups. The problem of two religious groups, local religion and official religion, can be simulated into a Lotka-volterra equation model. Originally, Lotka-Volterra was employed to depict the model of relation between prey and predator in the ecological realm[4]. This mathematical model has prominently being used in the matter of biology. Nevertheless, its application cannot be restricted in the area of life science. As long as there are interactional variables that influence the rate or number of each other, Lotka-Volterra model will be 
significant as a mathematical model describing the phenomena. Hence, the interaction of local religion and official religion is possible to illustrate in a Lotka-Volterra model. The Lotka-Volterra system of differential equations is a combination of 2 nonlinear differential equations[5]. Mathematically, this two-population interaction model was introduced by an American biophysicist, Alfred J. Lotka (1880-1949) and a prominent Italian mathematician, Vito Volterra (1860-1940). Both developed this mathematical study separately,

The lotka-volterra equation can be written as follows:

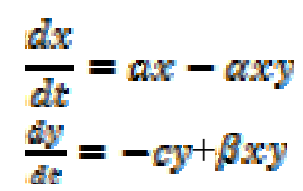

Description: $x(t)=$ number of prey population (prey) at time $\mathrm{t}$

$y(t)=$ population of predators (predators) at time $\mathrm{t}$

$\mathrm{a}=$ growth rate of prey

$\alpha=$ growth rate of the predator while preying

$c=$ predator death rate because there is no prey

$\beta=$ growth rate of predator after prey memang

Where $a, c, \alpha, \beta$ is a positive constant.

If $\mathrm{x}$ is defined as the number of prey populations (Prey) and $\mathrm{y}$ as the number of predator populations (Predator) interacting in an area at time t. The following assumptions make up the two-species interaction model, based on Lotka-Volterra[6]:

1. If the predator population is ignored, then the prey population growth rate will approach exponential and unlimited, so we get: $\frac{d x}{d t}=a x, a \geqslant 0$ when $y=0$

2. If the prey population is neglected, then the growth rate of the predator population will decrease, so that: $\frac{d y}{d t}=-c y, c>0$ when $x=0$.

3. Every interaction between the two populations, will increase the growth of the predator population and hinder the growth of the prey population[7]. Therefore, the growth of the predator population will increase by as much as $\beta x y$, while the growth of the prey population will decrease by $-\alpha x y$, where $a$ and $\beta$ are positive constants.

The equilibrium point of a system is the point at which the system does not change over time. The system of differential equations has the general form:

$$
\begin{aligned}
& \frac{d x_{1}}{d t}=f_{1}\left(x_{1}, x_{2}, \ldots, x_{n}\right) \\
& \frac{d x_{2}}{d t}=f_{2}\left(x_{1}, x_{2}, \ldots, x_{n}\right) \\
& \vdots \\
& \frac{d x_{n}}{d t}=f_{n}\left(x_{1}, x_{2}, \ldots, x_{n}\right)
\end{aligned}
$$

Where $f_{n}$ is a function with $n=1,2,3, \ldots$. The definition of the equilibrium point can be written in the following definition:

Point $\left(x_{1}{ }^{*}, x_{2}{ }^{*}, \ldots, x_{n}^{*}\right)$ is called the equilibrium point of the system of differential equations if $f_{1}\left(x_{1}{ }^{*}, x_{2}{ }^{*}, \ldots, x_{n}^{*}\right)=0, f_{2}\left(x_{1}^{*}, x_{2}{ }^{*}, \ldots, x_{n}^{*}\right)=0, \ldots, f_{n}\left(x_{1}^{*}, x_{2}{ }^{*}, \ldots, x_{n}{ }^{*}\right)=0$. $[8]$

Local religion is assumed as prey variable and official religion is assumed as predator variable. When the official religion spreads religion, then religion is the conversion of adherents of local religions to the official religion. Here the local religious population will decrease. The more the population of the official 
religion, the less the population of the local religion. This form of interaction can be modeled into a LotkaVoltera system of equations. The Lotka-Volterra system of equations is a first-order nonlinear differential equation system that is often used to describe the interaction of two species, where one species is a predator and the other is a prey.

\section{METHODS}

In this study, the author will describe how the research approach will be used in forming valid new knowledge. Researchers must adapt and contextualize research methods for the specific investigation that will be carried out. [9] Establishing research methods and approaches is an important thing that needs to be done. This is because with the right method, researchers will be able to get answers to the problems posed in their research [10]. In addition, the use of adequate research methods also supports the recognition of feasibility and validity from the scientific community, and shows that the research carried out is reliable and valid. Among the many existing methods, this research is a mathematical research that uses literature to obtain solutions to the given problems [9]. The case raised and will be modeled is the interaction between local religion and official religion. The adherents of the two religious groups interact by transferring or converting from adherents of the local religion to the official religion. The modeling in this study uses the Lotka-Voltera system of equations. This system of equations was originally a system used to describe the interaction between prey and predator. However, due to its usefulness and the emergence of identical cases, it makes Lotka-volterra also used in economic, social and political fields. The case raised and will be modeled is the interaction between local religion and official religion. The adherents of the two religious groups interact by transferring or converting from adherents of the local religion to the official religion. The modeling in this study uses the Lotka-Voltera system of equations. This system of equations was originally a system used to describe the interaction between prey and predator. However, due to its usefulness and the emergence of identical cases, it makes Lotka-volterra also used in economic, social and political fields. The case raised and will be modeled is the interaction between local religion and official religion. The adherents of the two religious groups interact by transferring or converting from adherents of the local religion to the official religion.

This system of equations was originally a system used to describe the interaction between prey and predator. However, due to its usefulness and the emergence of identical cases, it makes Lotka-volterra also used in economic, social and political fields. This system of equations was originally a system used to describe the interaction between prey and predator. However, due to its usefulness and the emergence of identical cases, it makes Lotka-volterra also used in economic, social and political fields. This study uses a literature study, meaning that all materials in this study were taken, collected, and compiled from various existing literature sources. The materials used include the Lotka-Volterra equation, equilibrium and stability, system linearization. In order to solve the problems presented so that they are in accordance with the objectives to be achieved, the steps taken in this study are as follows[5]:

a. Find the equilibrium point (equilibrium points) from the Lotka-Volterra equation.

b.Analyzing the stability of the interaction of local religion and official religion based on the equilibrium point obtained from the equation Lotka-Volterra.

\section{RESULT AND DISCUSSION}

This section is the main part of the research article and is usually the longest part of an article. The research results presented in this section are "clean" results. Data analysis processes such as statistical calculations and hypothesis testing processes do not need to be presented. Only the results of the analysis and the results of hypothesis testing need to be reported. Tables and graphs can be used to clarify the presentation of research results verbally. Tables and graphs should be commented on or discussed. The Lotka-Voltera equation was introduced by an American biophysicist, Alferd J. Lotka (1880-1949) and a prominent Italian mathematician, Vito Volterra (1860-1940). The equation is a model that explains the interaction between prey and predators. Initially the equation was intended to explain interactions in the biological field. In its development, the equation is also used in various cases such as in economic, social and political. In a case 
where competition interaction occurs in a population, it can be applied in the Lotka-Voltera equation. In this study, the concept of prey-prey in biological studies will be associated with socio-religious phenomena, namely the interaction of local religion and official religion. The phenomenon of the interaction of official religion and local religion can be modeled with the Lotka-Voltera equation because the interaction of the two types of religion affects each other in terms of quantity. In religious studies, there is a phenomenon of conversion or conversion from one religion to another. This means that the interaction of two religions in the form of religious conversion causes a decrease in the number of adherents of a religion and an increase in the number of adherents of a religion. A social phenomenon such as religious conversion is not that simple. Sometimes there are many variables that influence and lead to unpredictable results. However, in modeling, researchers must be content to observe limited variables and ignore other variables. This is also the case in exact fields such as biology, from which the Lokta-Voltera equation was created. Once again, reductions and restrictions like this are not to ignore the complexity of the phenomenon, but to take a clearer picture of a phenomenon. And finally, we will realize that complexity occurs not only because of the many variables involved, Based on the Lotka Volterra equation, the population of official religions and local religions will occur at a point of equilibrium which is the point where the number of official religions and local religions is in a balanced state or does not experience conflict, three points of equilibrium are obtained, namely:

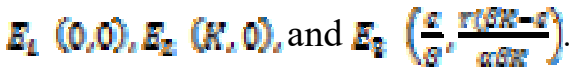

The Jacobian matrix of the system of differential equations is:

$$
\begin{aligned}
J_{(\bar{x}, \bar{y})}= & \left(\begin{array}{ll}
\frac{\partial f_{1}}{\partial x} & \frac{\partial f_{1}}{\partial y} \\
\frac{\partial f_{2}}{\partial x} & \frac{\partial f_{1}}{\partial y}
\end{array}\right)_{(\bar{x}, \bar{y})}=\left(\begin{array}{ll}
k_{11} & k_{12} \\
k_{21} & k_{22}
\end{array}\right) \\
f_{1}(x, y) & =r x\left(1-\frac{x}{K}\right)-\alpha y x \\
& =r x-\frac{r x^{2}}{K}-\alpha y x \\
f_{2}(x, y) & =-c y+\beta x y
\end{aligned}
$$

So the Jacobian matrix for the equilibrium point is as follows:

a.For the equilibrium point $(0,0)$

$$
J_{(0,0)}=\left(\begin{array}{cc}
r & 0 \\
0 & -c
\end{array}\right)
$$

b. $\quad$ For the equilibrium point $(K, 0)$

$$
J_{(0,0)}=\left(\begin{array}{cc}
-r & -\alpha K \\
0 & -c+\beta K
\end{array}\right)
$$

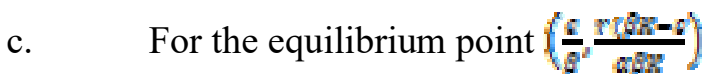

$$
J_{(0,0)}=\left(\begin{array}{cc}
\frac{-r c}{\beta K} & \frac{-\alpha c}{\beta} \\
\frac{r(\beta K-c)}{\alpha K} & 0
\end{array}\right)
$$

In the socio-religious world, interactions between official religion and local religion often lead to conflicts and disputes. In fact, in some cases, the interaction of the official religion and local religion causes a decrease in the population or adherents of the local religion. From Lotka-Voltera modeling, it is found that there are three equilibrium points. From this, a lesson can be drawn that the interaction of official religion and local religion does not have to lead to the extinction of a religious form. The interface of local religion 
and official religion has an equilibrium point, where in Indonesia society they are able to establish a tolerance and coexistent community.

\section{CONCLUSION}

Based on the results of the discussion, the following conclusions can be drawn:

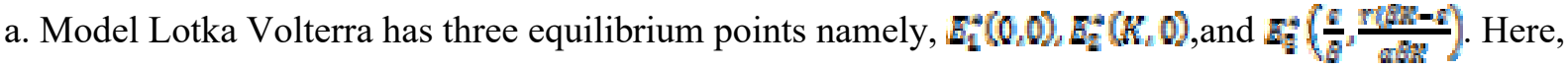
it shows that the interaction of official religion and local religion does not have to lead to the extinction of a religious form. The interaction of local religion and official religion has an equilibrium point, where in social reality they can work in harmony.

b. The stability of the interaction of local religion and official religion occurs at the equilibrium

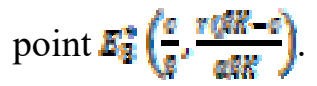

\section{REFERENCES}

[1] M. Rosyid, “Konversi agama masyarakat Samin,” UIN Walisongo Semarang, 2013.

[2] H. J, "Dinamika Hubungan Islam dan Agama Lokal di Indonesia: Pengalaman Towani Tolotang di Sulawesi Selatan," Wawasan J. Ilm. Agama dan Sos. Budaya, vol. 1, no. 2, pp. 179-186, 2016, doi: 10.15575/jw.v1i2.744.

[3] N. Hadi, "Penetrasi Agama Negara pada Komunitas Tengger di Kantong Taman nasional Bromo-TenggerSemeru," J. Sej. dan Budaya, vol. 2, no. 2, 2015.

[4] N. Sholihah, "ANALISIS KESTABILAN MODEL PREDATOR-PREY," Universitas Islam Negeri Maulana Malik Ibrahim, Malang, 2017.

[5] T. Hidayati, "KESTABILAN MODEL POPULASI MANGSA PEMANGSA DENGAN LAJU PEMANENAN TETAP," Delta J. Ilm. Pendidik. Mat., vol. 6, no. 1, p. 38, 2018, doi: 10.31941/delta.v6i1.500.

[6] N. K. Vitanov, Z. I. Dimitrova, and M. Ausloos, "Verhulst-Lotka-Volterra (VLV) model of ideological struggle," Phys. A Stat. Mech. its Appl., vol. 389, no. 21, pp. 4970-4980, Nov. 2010, doi: 10.1016/j.physa.2010.06.032.

[7] J. Reece, Urry, Cain, Wasserman, Minorsky, Campbell biology. Boston: Pearson, 2005.

[8] N. Bellomo and L. Preziosi, Modelling mathematical methods and scientific computation. 1994.

[9] A. Dresch, D. P. Lacerda, and J. A. V. Antunes, "Design Science Research," in Design Science Research, Springer International Publishing, 2015, pp. 67-102.

[10] K. M. Colin Robson, Real World Research, 4th Edition. 2016. 